\title{
El sentido crítico y los medios de comunicación
}

\author{
Dr. Francisco Estupiñán Bethencourt \\ Periodista. \\ Jefe del Gabinete de Comunicación de la Consejería de Empleo y Asuntos Sociales.
}

Gobierno de Canarias

El autor reflexiona sobre la importancia de una mente crítica en el receptor de mensajes pero indica cómo no pocos de esos mensajes contribuyen a que esa mente crítica no se desarrolle y se estanque. Este aspecto no es nuevo -reconoce el autor-pero se ha incrementado cuantitativamente y cualitativamente en la actualidad con la explosión comunicacional de la sociedad red. Ahora bien, el doctor Estupiñan no olvida que la mente crítica tiene un basamento fundamental: la educación desde las primeras fases a las últimas.

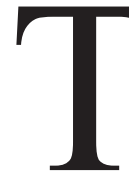

anto desde el punto de vista del sentido común de los individuos como de las propias libertades que éstos disfrutan en las sociedades democráticas, en las que se postula la condición no alineada del hombre, el sentido crítico es una premisa básica de la libertad de los sujetos, en tanto que es esa capacidad de discriminamiento y juicio propio la que otorga una autonomía en la toma de decisiones.

Ahora bien, ese denominado sentido crítico de cualquier individuo fundamenta su formación en la educación que haya recibido previamente y su correcta asimilación, que es la que otorgará los elementos de juicio indispensables para extraer conclusiones por sí mismo que determinen sus ulteriores posicionamientos ante cualquier mensaje recibido, sea éste personal, profesional, informativo, académico, artístico o de cualquier otra índole.

Pero si estas valoraciones generales se aplican estrictamente al sentido crítico de los receptores de mensajes específicamente generados por los medios de comunicación social, su capacidad de formarse un juicio propio no sólo está condicionada por su actitud ante la información, sino que, además, está sujeta a otras interacciones que proceden del medio informativo y del emisor de ese mensaje, el periodista.

Por ello, en las sociedades democráticas, a pesar de que por su propia naturaleza política consagran como derechos básicos la libertad de expresión y el derecho a la información, las empresas y los profesionales de la información intentan, voluntaria o involuntariamente, predeterminar con sus mensajes las conductas de receptores, distorsionando su sentido crítico y consiguientemente, sus conclusiones. 
En este estado de cosas seguramente siempre ha existido desde que el hombre ha sido capaz de generar mensajes informativos y desde el momento en que fue consciente de que podía influir en la opinión de sus congéneres a través de distintos procedimientos, que van desde la simple y sana capacidad de persuasión a la más compleja e insana capacidad de manipulación, alternando el propio sentido crítico individual.

Pero, si bien esto es cierto, tampoco es menos verdad que estas capacidades han aumentado su vigor durante el siglo XX con la aparición de nuevos medios de comunicación distintos de la prensa -radio, televisión-, y por el desarrollo tecnológico, que ha permitido una asombrosa rapidez y fiabilidad en la transmisión de comunicaciones -informática, satélite, cable-, a pesar de las distancias que puedan separar el lugar donde se produce un acontecimiento de interés general y el lugar en el que se difunden esos mismos hechos.

\section{Los medios de comunicación y el sentido crítico}

Desde que, en el siglo XV, entrara en funcionamiento la primera imprenta tipográfica $\mathrm{y}$, así, se empezaran a tener las primeras condiciones técnicas para dar lugar al primer medio de comunicación masivo, la prensa, las primeras noticias de mano y gacetas pretender ya influir en la opinión pública, pero el paso del tiempo y el desarrollo de las comunidades humanas han cambiado esa capacidad de alterar el sentido crítico de los receptores, a la vez que las condiciones de vida de éstos han variado notablemente: Antes del capitalismo post-industrial, las empresas (periodísticas) eran pequeñas: sus enclaves urbanos están constituidos por villas de poca población de mediano espacio edificado. En este sentido, los periódicos pocos números, pocas páginas; eran más ideológicos que económicos, podían salir a la calle con una reducida redacción, que, al mismo tiempo, operaba una imprenta dotada de escasa maquinaria (...) Ahora con el gran capitalismo, que ha creado las grandes megalópolis, las empresas multinacionales, los periódicos son poderosas empresas industriales de la información, más proclives al fetichismo de la mercancía que al idealismo político de las primeras gacetas o noticias de la mano ${ }^{1}$.

$\mathrm{Y}$ cierto es que, con estos cambios vertiginosos de las sociedades humanas producidos en los últimos cinco siglos, las empresas informativas no son ya aquellas entidades que difundían una determinada ideología política. Hoy, como señala Abraham Gillén, son consorcios que idealizan su propia mercancía superestructural, la información y la opinión, una vez que éstas han demostrado su capacidad para condicionar la vida política, determinar el curso económico o desentrañar un crimen y su autoría.

Guillén Abraham: Técnicas de desinformación. Editorial Fundación Anselmo Lorenzo. Madrid, 1991. Página 25. 
Pero hay que aclarar que este desarrollo de la industria de los medios de comunicación, que no su importancia social, sólo ha sido posible en el marco de las democracias parlamentarias, ya que sin libertad de información hay dictadura política, no hay protección contra la tiranía de un dictador o de un partido único, no hay posibilidad de difundir la verdad ante el pueblo; sin libertad de expresión no se pueden proteger las declaraciones públicas; expresar las ideas libremente; gozar abiertamente de los derechos fundamentales y de las libertades esenciales del hombre ${ }^{2}$.

Efectivamente, las condiciones de libertad en las que desarrollan sus fines los medios de comunicación en las sociedades democráticas no tienen parangón con las condiciones en las que éstos ejercen su trabajo en regímenes de dictadura unipersonal o de partido único, en los que se ven sometidos a la censura previa de las informaciones o al directo control de los medios por el poder.

Más, ello no debe hacer pensar que los medios de comunicación en las democracias (sean prensa, radio o televisión) no manipulan los contenidos informativos, aunque sólo sea en el ejercicio de la inevitable autocensura o por la falta de referentes contextuales en ciertas emisiones de opiniones, y por tanto distorsionan el sentido crítico de sus receptores. Si lo manipulan, en ocasiones de forma directa $y$, otra veces, de forma indirecta.

Cabe entender, en este sentido, por manipulación informativa indirecta la que es resultado de reproducir informaciones que se explican en un contexto cultural dado y que, visto desde la óptica de una civilización distinta o de forma parcial, producen rechazo en la conciencia de los receptores de los mensajes, según se expongan los hechos y, también, dependiendo de la consistencia del sentido crítico de estos últimos.

Para ilustrar este planteamiento, sirve recordar la no tan lejana controversia y rechazo público que se produjo en Francia, primero, y en España, después, con la difusión en distintos medios de las ablaciones clitoridianas de inmigrantes adolescentes de origen africano, que se expusieron a la opinión pública como horrendas mutilaciones físicas y graves lesiones a la integridad moral de las jóvenes. Si, bien al contrario, tales informaciones se hubieran producido en el país de origen de los inmigrantes afectados -en donde no son noticia en realidad-, estas ablaciones están consideradas dentro del respeto a las tradiciones y se hubiera felicitado a las afectadas por su entrada ritual en el mundo de los adultos.

Podríamos considerar manipulación directa, de una información de interés general sustraerla a la consideración pública o tratar el mensaje a difundir de tal manera que altere los hechos o condicione la interpretación que de estos puedan hacer los receptores, manipulando así su capacidad de formarse un juicio crítico. En este sentido, cabe recordar lo sucedido con el diario El Mundo, que en su

2 Ibídem, página 27. 
empeño de denunciar casos de corrupción que puedan vincularse al ex presidente del Gobierno Felipe González publicó una supuesta compra de droga de la cadena de televisión pública para que un drogadicto se inyectara durante la grabación de un reportaje, cosa que, pudo comprobarse que era falsa.

Al respecto hay que destacar que el segundo caso es menos común y frecuentado que el primero, pues obviar de forma sistemática determinadas informaciones significaría poner en tela de juicio la libertad de expresión y el derecho a la información y, por ende, se estaría menoscabando el estado de derecho que fundamenta la convivencia democrática, con sus consiguientes peligros y descréditos.

Esta capacidad de influir en la opinión pública o, dicho de otro modo, de alterar el sentido crítico de los receptores de la información, tendría un relieve menor de producirse hace unos cientos de años, pero el avance científico y tecnológico de los últimos tiempos ha incrementado de forma obstensible las vías y la capacidad de influencia de los mass media, entre otras razones, por el aumento considerable de la difusión en lo que Jean-François Revel denomina sociedad abiertas (democráticas): En nuestro siglo se encuentran a la vez más conocimientos y más hombres que conocen esos conocimientos. En otras palabras, el conocimiento ha progresado, y aparentemente ha sido seguido en su proceso por la información, que es su diseminación entre el público, a lo que añade: (...) Occidente ha comprendido desde hace tiempo que en una sociedad que respira gracias a la circulación de información, regular esa circulación constituye un elemento determinante del poder ${ }^{3}$

Y efectivamente, el control de la difusión de las noticias por los medios de comunicación es un ejercicio de poder diario de estos, que en la actualidad ha conseguido la inmediatez de su exposición pública a través de la radio y el impacto de la imagen en movimiento con la televisión, por lo que lo que se ha dado en llamar galaxia Gutenberg tiene que compartir sus privilegios de antaño.

Y corroborado el axioma de que el control del flujo de información es una forma de poder que adquiere notable vigor en el siglo XX, vale la pena adentrarse en cómo la industria de la información se conforma para expandir, ala par, ese poder de influir en los receptores y vulnerar su sentido crítico. La primera consideración, y más obvia, es que en el presente obstentar la titularidad de un medio de comunicación requiere de no pocos recursos económicos que hacen que sus propietarios sean personas o entidades que acumulen importantes riquezas. Esta afirmación es evidencia cuando se conoce que la puesta en marcha de una empresa dedicada a la prensa requiere una inversión cuantificada en cientos de millones, cantidad que asciende a los miles de millones si hablamos de una cadena de televisión.

3 Revel, Jean-François: El conocimiento inútil. Editorial Planeta. Barcelona, 1989. Página 9. 
Tal capacidad inversora de la mayoría de las sociedades que sustentan a los medios informativos y el poder que estos generan han motivado, a su vez, que las mismas constituyan trust que se extiende a la producción de materias primas como el papel o regentar distintos medios y de diversa naturaleza. Esta situación está ilustrada en España con el ejemplo notorio del grupo PRISA, propietario no sólo del rotativo nacional de mayor tirada, El País, sino de la Sociedad Española de Radio Difusión (SER), de la cadena de televisión de pago Canal +, del Canal Satélite Digital y de una productora cinematográfica, entre otras.

Esta circunstancia tiene una influencia trascendental sobre el sentido crítico de los receptores, en tanto que para que este sentido crítico tenga rudimentos en los que forjarse necesita de forma imperativa de la pluralidad informativa que sirva de contraste por las distintas versiones de los hechos noticiables, pues estos poderosos trust informativos condicionarán una valoración unitaria tanto de las informaciones como de sus interpretaciones, por lo que, aún acudiendo a distintos medios, el receptor se encontrará con una misma visión de los hechos y, por lo tanto, obtendrá unos únicos elementos con los que formar su juicio sobre ellos. Si a este hecho sumamos que los estudios de difusión o audiencia no sólo cumplen el cometido para la publicidad, sino que ayuda a configurar una visión unitaria del mundo que reflejan las propias audiencias; esto es, se sabe lo que el público quiere y lo que rechaza y estos datos condicionan luego el ejercicio profesional.

\section{El periodista y el receptor}

En cualquier caso, si bien es cierto que la empresa de comunicación -el medio del circuito comunicativo- mediatiza sus mensajes y los condiciona haciendo valer tanto sus intereses políticos como económicos, no es cierto que el profesional de la información -el emisor de los mensajes-, también ve condicionado su trabajo, en algunos casos, por intereses espurios, pero no es lo más frecuente. La circunstancia más general es que el periodista ejerza la autocensura sobre su producción a la que aludíamos más arriba de acuerdo con los específicos intereses de su medio para evitar, así, que sean otras instancias las que modifiquen su trabajo sin que él mismo conozca el alcance de estos cambios.

Más el periodista, por su propia actividad profesional, suele tener un agudo sentido crítico y, tal y como decía uno de los personajes del director cinematográficos Francis Ford Coppola en su película Cotton Club, ve, oye y saca sus propias conclusiones y una de las primeras que suele adoptar en su actividad es que tiene que adaptarse a la línea que le marca su empresa, más cuando ejerce una profesión con un número significado de desempleados y en la que se puede llegar a padecer el ostracismo de por vida, sobre todo contando con el inmovilismo de sus propios receptores: Pero dígase lo que se quiera del periodismo (...), debemos guardarnos de incriminar a los periodistas. Si un número reducido de ellos, en efecto, sirve 
realmente al ideal teórico de su profesión es porque (...) el público apenas le incita a ello ${ }^{4}$.

Es decir, que el público, los receptores de los mensajes, se revelan una y otra vez como un conjunto de individuos con escaso sentido crítico en tanto que, de las realidades que se les comunica a través de los medios de comunicación social, apenas se produce una reflexión que induzca a la acción, responsabilidad que, por otra parte, atañe no sólo a estos, sino también a los emisores y al medio: (...) la impotencia de la información para eliminar la acción, o, incluso, simplemente la convicción, sería una desgracia banal si no fuera consecuencia más que de la censura, de la hipocresía y de la mentiras.

Como ya ha quedado dicho, la censura en todas sus formas la ejercen los medios de comunicación y los periodistas, pero la hipocresía y la mentira es un ejercicio colectivo en el que también está implicado el público, como prueba el hecho de que en países que son ejemplo de desarrollo social, como el caso de Alemania, Gran Bretaña, exista una prensa sensacionalista, dedicada a la noticia frívola y a la deformación de los hechos para que estos ganen en impacto e impresión, que tiene unas ventas superiores a lo que denominamos prensa seria. Y efectivamente, el público está más interesado en las cuitas sentimentales de personajes famosos que en la impecable extensión del sida entre la población africana, pongamos por caso.

A los receptores, las noticias les interesan cada vez no por su interés general, sino por su capacidad de impacto, de provocar sensaciones e impresiones que violenten los sentidos o agudicen la percepción intelectual: (...) la información es considerada directamente proporcional a la imprevisión máxima y, por lo tanto, a la entropía. Y por esto, con la tendencia a una imprevisión máxima se tiende a una situación en la que la información del mensaje sea máxima ${ }^{6}$. Si esta circunstancia de imprevisión por los receptores no se produce sólo difícilmente se captará la atención al lector, por lo que la elaboración de la información exige cada vez más titulares espectaculares o sensacionalistas que atrapen al público, aún a riesgo de desvirtuar los contenidos.

Pero ni siquiera estas técnicas incitan a la reflexión y la acción de los receptores, que se limiten a disfrutar del impacto de las impresiones, pero sin que la información los motive a ir más allá y se produzca una interacción entre los mensajes informativos y las audiencias. Un ejemplo de ello fue el uso reciente de imágenes televisivas de personas, especialmente niños, lacerados por la lacra del hambre en Ruanda, a las que el público reaccionó con una gran impresión y se produjo una actitud de auténtica solidaridad con los afectados, pero las iniciativas

4 Ibídem, página 17.

6 Dorfles, Guillo: Símbolo, comunicación y consumo. Editorial Lumen. Barcelona, 1984. Página 45. 
que se produjeron fueron de organizaciones humanitarias o de personajes públicos que se prestaron para motivar estas conductas solidarias con la colaboración de los propios medios de información, que actuaron de inductores. Y en este caso se produce una doble manipulación: la primera es permitir que el árbol no deje ver el bosque. Lo que se quiere decir es que el problema de una región africana más amplia, en lo que también se incluye Ruanda, vive en régimen de tiranía, con conflictos étnicos permanentes y con un crecimiento del sida que hará que sea la epidemia más grande de las que a los hombres han azotado.

Éste sería el contexto sincrónico en el que se produce la guerra civil de Ruanda y sus posteriores consecuencias y, por lo tanto, es la única realidad que, de variarse, podrían al menos mitigar la gran catástrofe que vive prácticamente toda el Africa negra. Las acciones aisladas, en cambio, no darán a unas circunstancias de vidas mejores y perdurables por lo que no rentabilizarán los recursos asignados.

Probablemente, toda esta ausencia de sentido crítico de los receptores de los mensajes informativos, especialmente en las sociedades democráticas, esté condicionada por las conductas que generan el sistema económico capitalista de estas sociedades en las que se confunde egoísmo con individualismo y donde la acumulación de riqueza es una de las premisas básicas de los valores personales. Desde esta óptica también se podría explicar por qué nos interesa más al público la vida privada de los personajes famosos, que se constituyen en modelo a seguir por sus riquezas y su vida social, que el hecho de que la población de Bosnia-Herzegovina o Kosovo fuera masacrada, por mucho que esta guerra se haya producido a gran proximidad geográfica.

\section{Conclusión}

Esta atrofia del sentido crítico de los receptores de los mensajes informativos, teledirigida en algunos casos por los propios medios, condiciona toda la comunicación social: (...) Se invoca sin cesar en esas sociedades (democráticas) un deber de informar y un derecho a la información. Pero los profesionales se muestran tan solícitos en traicionar ese deber como sus clientes tan desinteresados en gozar de ese derecho $(\ldots 1)^{7}$.

Pero la condiciona de tal modo que, de la misma manera que podría promover la inferencia de las audiencias de los medios de comunicación masivos en todas aquellas cuestiones que necesitan de la determinación y la solidaridad, se convida a participación activa de los receptores de los mensajes en aquellas situaciones sin efectos directos sobre terceros (los programas de ocio y variedades, por ejemplo) o cuando la injerencia se circunscribe al ámbito más cercano y

7 Revel, Jean-François: El conocimiento inútil. Editorial Planeta. Barcelona, 1989. Página 11. 
personal de las audiencias (los reality show, valga el caso). La participación en fenómenos sociales sólo se índice, normalmente en programas de carácter informativo.

Generalmente, para que los medios procedan así la noticia se tiene que dar con preferencia fuera de las fronteras de los países más desarrollados -excepción hecha de los sucesos- $\mathrm{y}$ tiene que estar unida a circunstancias humanas extremas, como la guerra o las epidemias, llegando incluso a la toma de partido expresa de los medios, como ocurrió en la última guerra en el golfo Pérsico. Y por el contrario, todas las justificaciones y exigencias que motivaban la conflagración siguen vigentes, como es el hecho de que se mantiene idéntico régimen y gestionado por las mismas personas.

Pero todas estas circunstancias no parecen condicionar en absoluto a los receptores de los mensajes más allá de generar unas opiniones. Además, es axiomático que la proliferación de un mismo hecho noticiable logra incluso provocar una distorsión continuada en el proceso comunicativo, al producir como reacción en las audiencias lo que podríamos denominar automatización de la percepción: unos determinados acontecimientos reiterados inhiben finalmente a los receptores de las impresiones que los hechos puedan o deban promover. Éste es el caso de los conflictos en la ex Yugoslavia. No obstante, y porque la crueldad se prolongue tanto en el tiempo, la guerra en la ex Yugoslavia sea hoy menos que nunca un hecho noticiable de impacto, esto es, las audiencias tienen su percepción ya desinhibida y tan estereotipadas por la inacción social por la reiteración informativa. 